\title{
Pusa Wheat HI 8805: A high yielding durum wheat variety for timely sown, restricted irrigation conditions of Peninsular Zone of India
}

\author{
Divya Ambati ${ }^{*}$, Sakuru Venkata Sai Prasad ${ }^{1}$, Jang Bahadur Singh ${ }^{1}$, Rahul Madho Rao Phuke ${ }^{1}$, \\ Thorehalli Linganna Prakasha ${ }^{1}$, Akilesh Nandan Mishra ${ }^{1}$, Kailash Chandra Sharma ${ }^{1}$, Anil \\ Kumar Singh ${ }^{1}$, Gyanendra Pratap Singh ${ }^{2}$, Jai Bhagwan Sharma ${ }^{3}$, Pradeep Kumar Singh ${ }^{3}$, \\ Harikrishna Yadav ${ }^{3}$, Rajbir Yadav ${ }^{3}$, Sanjay Kumar ${ }^{3}$, Anju Mahendru Singh ${ }^{3}$, Neelu Jain ${ }^{3}$, Kiran \\ Bapusaheb Gaikwad ${ }^{3}$, Manjeet Kumar ${ }^{3}$, Vaibhav Kumar Singh ${ }^{3}$, Naresh Kumar ${ }^{3}$, Prasanth Babu \\ Hanumanthappa ${ }^{3}$, Raghunandan Katlukor ${ }^{3}$, Murugasamy Sivasamy ${ }^{4}$, Paramasivan Jayaprakash ${ }^{4}$, \\ Venu Kumaran Vikas ${ }^{4}$, Tapas Ranjan $\mathrm{Das}^{5}$, Dharam Pal ${ }^{6}$, Madhu Patial ${ }^{6}$, Ram Niwas Yadav ${ }^{6}$, \\ Kumble Vinod Prabhu ${ }^{7}$ and Ram Kumar Sharma ${ }^{3}$ \\ ${ }^{1}$ ICAR-Indian Agricultural Research Institute, Regional Station, Indore, Madhya Pradesh, India \\ ${ }^{2}$ ICAR-Indian Wheat and Barley Research Institute, Karnal, India \\ ${ }^{3}$ ICAR-Indian Agricultural Research Institute, New Delhi, India \\ ${ }^{4}$ ICAR-Indian Agricultural Research Institute, Regional Station, Wellington, Tamil Nadu, India \\ ${ }^{5}$ ICAR-Indian Agricultural Research Institute, Regional Station, Pusa, Bihar, India \\ ${ }^{6}$ ICAR-Indian Agricultural Research Institute, Regional Station, Karnal, India \\ ${ }^{7}$ Protection of Plant Varieties \& Farmers' Rights Authority, Government of India, New Delhi, India
}

Article history: Received: 26 Oct., 2020 Revised: 19 Jan., $2021 \quad$ Accepted: 11 March, 2021

Citation: Ambati D, SVS Prasad, JB Singh, RMR Phuke, TL Prakasha, AN Mishra, KC Sharma, AK Singh, GP Singh, JB Sharma, PK Singh, H Yadav, R Yadav, S Kumar, AM Singh, N Jain, KB Gaikwad, M Kumar, VK Singh, N Kumar, PB Hanumanthappa, R Katlukor, M Sivasamy, P Jayaprakash, VK Vikas, TR Das, D Pal, M Patial, RN Yadav, KV Prabhu and RK Sharma. 2021. Pusa Wheat HI 8805: A high yielding durum wheat variety for timely sown, restricted irrigation conditions of Peninsular Zone of India. Journal of Cereal Research 13(1): 102-106. http://doi.org/10.25174/2582-2675/2021/106452

*Corresponding Author: Email: divya.ambati@icar.gov.in

(c) Society for Advancement of Wheat and Barley Research

\begin{abstract}
A high yielding durum wheat variety HI 8805 (Pusa Wheat 8805) has been released and notified by the Central Sub-Committee on Crop Standards, Notification and Release of Varieties for Agricultural Crops, Government of India for commercial cultivation under timely sown, restricted irrigation conditions of Peninsular Zone (PZ) of the country. HI 8805 has an average yield of $30.4 \mathrm{q} /$ ha over the zone and showed significant superiority over the checks; with a potential yield of $35.4 \mathrm{q} / \mathrm{ha}$. It has shown an excellent and wider adaptation and significantly superior performance across different irrigation regimes over the checks with an average yield of $30.7 \mathrm{q} / \mathrm{ha}$. It showed high levels of field resistance to black and brown rusts. It has high protein content (12.8\%), yellow pigment content $(4.9 \mathrm{ppm})$, test weight $(83.7 \mathrm{~kg} / \mathrm{ha})$, sedimentation value $(42 \mathrm{ml})$, iron content $(40.4 \mathrm{ppm})$, zinc content ( $33.9 \mathrm{ppm})$ with an overall pasta acceptability (5.7). It can be used as a "dual quality" durum suitable both for "chapati making" as well as for pasta preparations. This variety has been found promising for timely sown, restricted irrigation areas of PZ; and thus, it will contribute to increase wheat production and will improve the socio-economic status of farmers.
\end{abstract}

Key words: Durum Wheat, Pasta quality, Disease resistance and Yield

\section{Introduction}

Wheat cultivation in India is about 30 million hectares with the production of 108 million tonnes (IIWBR

Director's Report, 2020). India is one of the leading durum wheat producing countries in the world with acreage of 
around 1.5 million hectares and production nearly 3.5 million tons (Tidiane et al., 2019). Durum wheat cultivation is mostly prominent in Central and Peninsular Zones (PZ) of India. The durum wheat cultivation in the PZ is mainly under rainfed and limited irrigation conditions (Biradar et al., 2015). To meet the challenges of drought stress, durum wheat varieties having early maturity, drought tolerance, disease resistance and good quality traits are being developed. Improving grain yield is the ultimate aim of wheat improvement programme in India. Yield increase may be effectively tackled on the basis of performance of yield components and related characters (Pal D et al., 2017).

Development and Notification of HI 8805: The variety HI 8805 was developed through modified pedigree method from the cross IWP 5070/HI 8638//HI 8663 by ICAR-Indian Agricultural Research Institute, Regional Station, Indore. It was released by the Central SubCommittee on Crop Standards through notification and release of varieties for agricultural crops viz., vide S.O. 91 E, dated 6.1.2020. HI 8805 was released for commercial cultivation of timely sown, restricted irrigation conditions of the PZ comprising Maharashtra, Karnataka and plains of Tamil Nadu.
Yield superiority and adaptability: This variety was evaluated in National coordinated evaluation trial under timely sown, restricted conditions (NIVT 5B) during 2016-17 in PZ. Under Co-ordinated trials of AICW\&BIP, HI 8805 was evaluated at 18 locations during 2016-17 to 2018-19 out of which it occurred 6 times in the first non-significant group indicating its wider adaptability and stable yielding feature (Table 1). HI 8805 was significantly high yielding durum wheat genotype (30.4 q/ha) compared to durum wheat check varieties AKDW 2997-16 (27.2 q/ha) and UAS 446 (26.4 q/ha) under restricted irrigation and timely sown conditions. (ICAR-IIWBR, 2019a). It has significant yield advantage of $11.6 \%$ and $12.9 \%$ over the checks AKDW 2997-16 and UAS 446, respectively. It has a potential yield of $35.4 \mathrm{q} /$ ha compared to durum wheat check varieties AKDW 2997-16 (34.6 q/ha) and UAS 446 (32.3 q/ha) under restricted irrigation and timely sown conditions. It also showed wider yield stability across the zone and yielded $>30.0 \mathrm{q} /$ ha at 10 out of 18 locations over three years of testing. HI 8805 was early to flowering (55-60 days), maturity (105-110 days) as compared to all the check varieties and possessed bold grains (TGW $48.0 \mathrm{~g}$ ).

Table 1: Summarized yield data of coordinated trials over Peninsular Zone (PZ)

\begin{tabular}{|c|c|c|c|c|c|}
\hline \multirow[t]{2}{*}{ Items } & \multirow[t]{2}{*}{ Year of testing } & \multirow{2}{*}{$\begin{array}{l}\text { No. of trials/ } \\
\text { location }\end{array}$} & \multirow{2}{*}{$\begin{array}{c}\text { Proposed variety } \\
\text { HI } 8805\end{array}$} & \multicolumn{2}{|c|}{ Durum wheat Check Varieties } \\
\hline & & & & AKDW 2997-16 & UAS 446 \\
\hline \multirow{4}{*}{$\begin{array}{l}\text { Mean yield } \\
(\mathrm{q} / \mathrm{ha})\end{array}$} & $1^{\text {st }}$ year $(2016-17)$ & 2 & 35.0 & 27.8 & - \\
\hline & $2^{\text {nd }}$ year (2017-18) & 8 & 28.7 & 25.7 & 25.9 \\
\hline & $3^{\text {rd }}$ year $(2018-19)$ & 8 & 30.9 & 28.6 & 26.9 \\
\hline & Weighted Mean & & 30.4 & 27.2 & 26.4 \\
\hline \multicolumn{3}{|c|}{$\begin{array}{l}\% \text { increase/ decrease over the checks \& qualifying variety : } \\
\text { Overall Weighted Mean }\end{array}$} & & $11.6^{*}$ & $12.9^{*}$ \\
\hline \multicolumn{3}{|c|}{$\begin{array}{l}\text { Frequency in the first top non-significant group :Pooled for } \\
\text { three years }\end{array}$} & $6 / 18$ & $2 / 18$ & $1 / 16$ \\
\hline
\end{tabular}

Distinguishing morphological characteristics: Durum wheat variety HI 8805 has erect growth habit and dark green foliage colour and anthocyanin pigmentation was absent on coleoptile at boot stage. It has erect, medium sized green flag leaf having strong waxiness on sheath and blade. Peduncle of HI 8805 is medium, with very dense, white coloured, strong waxy, parallel spike which bears white awn. The lower glume has medium sloping shoulder with medium straight beaks. It possesses amber coloured, oblong, medium sized, hard grain with medium germ width. 
Performance in agronomical evaluation: HI 8805 showed significantly higher yield $(30.70 \mathrm{q} / \mathrm{ha})$ in comparison to check varieties AKDW 2997-16 (27.98 q/ha), UAS 446 (27.84 q/ha) under different irrigation conditions when tested under co-ordinated agronomic trials during 2018-19. Under no irrigation, it recorded a superior yield of 9.5 to $10.4 \%$ over check varieties; while, under one irrigation, about 13.9 to $15.8 \%$, and under two irrigations, 6.1 to $6.4 \%$ increase was recorded over checks. It showed significant increase in grain yield under one irrigation (19.4\%) and two irrigations (46.1\%) compared to no irrigation (Anonymous, 2019). It showed significant increase $(9.0 \%$ to $11.7 \%$ in overall mean) for 1000 grain weight over all the checks.

Resistance to major disease and pests: $\mathrm{HI} 8805$ has high levels of field resistance to stem (Highest score: $5 \mathrm{~S}$; ACI:1.7) and leaf (Highest score: 10MS; ACI -1.9) rusts in comparison to check varieties in the second year of testing in AVT (ICAR-IIWBR, 2020b). However, it showed highest disease scores of $10 \mathrm{~S}$ for stem rust and 10MS for leaf rust during three years of screening under artificial inoculations, whereas the checks had highest disease scores of $20 \mathrm{~S}$ to $40 \mathrm{~S}$ for stem rust, and maximum of $20 \mathrm{~S}$ for leaf rust. It also showed good levels of adult plant resistance to prevalent and virulent stem rust pathotypes 117-6 and 40A. It also showed seedling resistance to stem rust pathotypes 15-1, 40-3, 40A, 117-6; and pathotypes of leaf rust race 77-group. It showed good levels of resistance to Karnal bunt, loose smut and foot rot; and better resistance to flag smut than all the checks and qualifying varieties. It was not affected by major insect pests.

Grain quality: HI 8805 is a high yielding durum wheat variety with high protein content $(12.8 \%)$, yellow pigment content $(4.9 \mathrm{ppm})$, test weight $(83.7 \mathrm{~kg} / \mathrm{hl})$ sedimentation value ( $42 \mathrm{ml})$, iron content ( $40.4 \mathrm{ppm})$, zinc content (33.9 ppm) with an overall pasta acceptability of 5.7. It can be used as a "dual quality" durum for chapati making or can be blended with bread wheat flour for chapati making, as it has sedimentation value of $42.9 \mathrm{ml}$. HI 8805 is also suitable for pasta product preparation with over all pasta acceptability of 5.7 (ICAR-IIWBR, 2019c). It has good levels of essential micronutrients like iron and zinc content making it rich in nutritional qualities. Hence, it can provide excellent raw material for the upcoming semolina-based fast food industries, generating additional employment opportunities and boosting farm economy.

In nutshell, the high yield potential variety HI 8805 couples with moisture stress tolerance and heat with plasticity for sowing time and resistance to major insect pests, stem and leaf rusts makes this variety a suitable choice for the farmers of $\mathrm{PZ}$ of the country.

Table 2: Adaptability to changes in agronomic conditions (2019-20)

\begin{tabular}{|c|c|c|c|c|}
\hline \multirow{2}{*}{$\begin{array}{l}\text { Experiment / } \\
\text { Item }\end{array}$} & \multirow[t]{2}{*}{ Irrigation levels } & \multirow{2}{*}{$\begin{array}{c}\text { Proposed variety } \\
\text { HI } 8805\end{array}$} & \multicolumn{2}{|c|}{ Durum wheat check varieties } \\
\hline & & & AKDW 2997-16 & UAS 446 \\
\hline \multirow[t]{4}{*}{ Yield (q/ha) } & I1 (No irrigation) & 25.20 & 22.82 & 22.93 \\
\hline & I2 (One irrigation) & 30.10 & 26.43 & 26.00 \\
\hline & I3 (Two irrigations) & 36.81 & 34.69 & 34.60 \\
\hline & Mean & 30.70 & 27.98 & 27.84 \\
\hline \multirow{3}{*}{$\begin{array}{l}\% \text { gain or loss } \\
\text { with irrigation } \\
\text { levels }\end{array}$} & $\mathrm{I} 2: \mathrm{I} 1$ & 19.4 & 15.8 & 13.4 \\
\hline & I3 : I1 & 46.1 & 52.0 & 50.9 \\
\hline & I3 : I2 & 22.3 & 31.3 & 33.1 \\
\hline \multirow{4}{*}{$\begin{array}{l}\text { \% superiority } \\
\text { over checks \& } \\
\text { qualifying variety }\end{array}$} & I1 (No irrigation) & & 10.4 & 9.9 \\
\hline & I2 (One irrigation) & & 13.9 & 15.8 \\
\hline & I3 (Two irrigations) & & 6.1 & 6.4 \\
\hline & Over mean & & $9.7^{*}$ & $10.3^{*}$ \\
\hline
\end{tabular}

$C D(P=0.05)$ : Irrigation $=1.09$; Variety $=1.51$; Variety within irrigation $=N S ;$ Irrigation within variety $=N S^{*}$ Significantly superior 
Table 3: Quality characteristics of wheat variety HI 8805

\begin{tabular}{lc}
\hline Quality trait & PZ \\
\hline Grain appearance (max score 10) & 7.7 \\
Test weight $(\mathrm{kg} / \mathrm{hl})$ & 83.7 \\
Sedimentation value $(\mathrm{ml})$ & 41.8 \\
Protein $\%$ & 12.5 \\
Yellow berry incidence $(\%)$ & 2.0 \\
Yellow pigment (ppm) & 5.0 \\
Fe (ppm) & 40.4 \\
Zn (ppm) & 33.9 \\
\hline Pasta Cooking Quality & \\
\hline Cooking time (min./sec.) & 11.0 \\
Water absorption (\%) & 120.6 \\
Water uptake ratio & 1.20 \\
Gruel solid loss (\%) & 5.0 \\
Stickiness & PS \\
Pasta Sensory evaluation & \\
Colour & 6.0 \\
Texture & 5.9 \\
Flavour/ Aroma & 5.4 \\
Taste & 5.5 \\
Overall Acceptability & 5.7 \\
\hline
\end{tabular}

\section{Acknowledgement}

The article is based on the CVRC proposal and the authors are highly thankful to all principal- investigators (Crop Improvement, Crop Protection, Quality \& Resource Management) and all the cooperators of peninsular zone for their contribution.

\section{References}

1. Anonymous 2019. Progress Report of All India Coordinated Research Project on Wheat and Barley 2018-19, Vol. II, Resource Management. Eds: Ramesh Kumar Sharma, Subhash Chandra Tripathi, Subhash Chander Gill, Rajender Singh Chhokar, Raj Pal Meena, Ankita Jha, Ajay Verma and Gyanendra Pratap Singh. ICAR-Indian Institute of Wheat and Barley Research, Karnal, Haryana, India. pp. 171.
2. Biradar SS, RV Naik, RR Hanchinal, BN Patil, IK Kalappanavar and SA Desai. 2015. A high yielding durum wheat variety UAS-428 released for cultivation to areas of Peninsular India. Green Farming 6 (3): 580-582.

3. ICAR-IIWBR. 2019a. Progress Report of AICRP on Wheat and Barley 2018-19, Crop Improvement. Ed(s): Gyanendra Singh, Ravish Chatrath, BS Tyagi, SK Singh, Arun Gupta, Satish Kumar, CN Mishra, K Venkatesh, Vikas Gupta, Charan Singh, Gopala reddy K, Hanif Khan, Raj Kumar, AK Sharma, Mamrutha HM, Bhumesh Kumar, Lokendra Kumar, Sindhu Sareen, Ratan Tiwari, Sonia Sheoran, Rinki, Ajay Verma, Suman Lata, Rekha Malik, OP Ahlawat, Rajender Singh, Pradeep Sharma and GP Singh. ICAR-Indian Institute of Wheat and Barley Research, Karnal, Haryana, India. pp. 165. 
4. ICAR-IIWBR. 2019b. Progress Report of All India Coordinated Wheat and Barley improvement Project 2018-19, Crop Protection Eds: Sudheer Kumar, D.P. Singh, Poonam Jasrotia, Prem Lal Kashyap and Gyanendra Pratap Singh. ICAR- Indian Institute of Wheat and Barley Research, Karnal, Haryana, India. pp. 214.

5. ICAR-IIWBR. 2019c. Progress Report of All India Coordinated Research Project on Wheat and Barley 2018-19, Wheat Quality. Eds: Sewa Ram, Sneh Narwal, O.P. Gupta and G.P Singh. ICAR-Indian Institute of Wheat and Barley research, Karnal, Haryana, India. pp-161.

6. ICAR-IIWBR. 2020. Director's Report of AICRP on Wheat and Barley 2019-20, Ed.: G.P. Singh. ICAR-Indian Institute of Wheat and Barley Research, Karnal, Haryana, India. pp.76.
7. Pal D, M Patial, KV Prabhu, J Kumar, S Watpade, RN Yadav, S Kumar, RK Sharma, GP Singh, R Yadav, Vinod, AM Singh, SV Sai Prasad, IS Solanki, M Sivasamy, JB Sharma, PK Singh, N Jain, N Mallik, K Gaikwad, TR Das, Vikas, Jaya Prakash, JB Singh, D Ambati, V Singh, AN Mishra, Shivadhar and A Arora. 2017. 'Central Wheat HS562' - a high yielding wheat variety for timely sown production conditions of Northern Hill Zone. Journal of Wheat Research 9(2):115-120.

8. Tidiane Sall A, T Chiari, W Legesse, K Seid-Ahmed, R Ortiz , M van Ginkel and FM Bassi. 2019. Durum wheat (Triticum durum Desf.): Origin, cultivation and potential expansion in sub-saharan Africa. Agronomy 9(5):263. 